\title{
IMPLEMENTASI REGULASI PENYIARAN AGAMA DI KOTA MAKASSAR
}

\author{
AKMAL SALIM RUHANA*
}

\begin{abstract}
Abstrak
Penyiaran agama merupakan salah satu topik krusial dalam hubungan antaragama. Dakwah oleh muslim dan misionari Kristen di wilayah garap yang sama, misalnya, kerapkali berkompetisi dan/atau menjadi konflik. Pemerintah mengatur lalu lintas hubungan antarumat beragama dengan menerbitkan peraturan, yakni: SKB Menag dan Mendagri No. 1 Tahun 1979 tentang Tatacara Pelaksanaan Penyiaran Agama dan Bantuan Luar Negeri kepada Lembaga Keagamaan di Indonesia. SKB yang (oleh beberapa pihak) dinilai kedaluwarsa ini kini mengalami tantangan di tengah masyarakat yang kian dinamis. Maka diperlukan pemutakhiran ataupun revisi. Penelitian ini mencoba mendalami implementasi regulasi ini dengan mengumpulkan pendapat dari masyarakat luas. Melalui studi pustaka, wawancara, dan observasi. Penelitian ini ditulis dengan metode deskriptif-analitis. Temuan penelitian ini antara lain: kini di Makassar tidak lagi ada praktik penyiaran agama dengan iming-iming hadiah, uang, pakaian, dsb., dalam rangka memindahagamakan orang yang sudah beragama lain. Sedangkan soal bantuan luar negeri dan penggunaan tenaga keagamaan asing belum pernah terdeteksi dan tercatat di Pemerintah Daerah: tak terkontrol.
\end{abstract}

\section{Kata KunCI:}

Penyiaran Agama, Bantuan Luar Negeri, SKB, Revisi

\section{Abstract}

Religious broadcasting remains one of the most crucial topics in inter-religious relationship. When Islamic dawah and Christian missionary share the same fields, a potential conflict and competition occurs. Indonesian government regulates this issue by issuing The Joint Decree of the Minister of Religious Affairs and the Minister of Home Affairs No.1 year 1979 on the Procedures of Religious Propagation and Foreign Aids to Religious-based Organization in Indonesia. This decree, which was regarded as outdated by some parties, is facing the challenges of the more dynamic society. Thus, it needs some updates or revisions for the decree. This study attempts to explore the implementation of this joint decree by collecting the responses from the society. By employing literature review, interviews, and observations, this study takes form of descriptive analytical method. It is found that there are no more religious conversion tricks by offering incentives such as: money, gifts, or clothing in Makassar. Meanwhile, foreign aids or facilities are not detected and recorded by the local authorities therefore they are out of control.

\section{KeY WoRDS: \\ Religious Propagation, Foreign Aid, Joint Decree, Revision}

\footnotetext{
*Peneliti pada Puslitbang Kehidupan Keagamaan, Badan Litbang dan Diklat Kemenag RI Jl. M. H. Thamrin No. 6 Jakarta. Surel: akmalsalimruhana@gmail.com.

** Naskah diterima Agustus 2015, direvisi September 2015, disetujui untuk dimuat Oktober 2015.
} 


\section{A. Pendahuluan}

Dua hal yang menonjol sebagai faktor yang potensial mengganggu kerukunan antar-umat beragama di Indonesia adalah kasus pendirian rumah ibadat dan kasus penyiaran agama. ${ }^{1}$ Kasus terkait rumah ibadat mewujud dalam bentuk perselisihan dalam pendirian, penertiban, atau penutupan rumah ibadat hingga penyerangan aktivitas ibadat dan perusakan rumah ibadat. Jumlah kasusnya cukup banyak dan dirasakan oleh hampir semua agama yang pemeluknya menjadi minoritas di suatu daerah. Dalam beberapa tahun terakhir, menurut sejumlah laporan, jumlah kasusnya mengalami kecenderungan meningkat. ${ }^{2}$ Adapun kasus terkait penyiaran agama mewujud dalam gesekan antar penyiar agama, kontestasi simbol agama, ataupun perebutan pemeluk. Kasus penyiaran ini tidak terlalu menonjol, meskipun pada praktiknya di beberapa wilayah diketahui ada. ${ }^{3}$

Kedua faktor dominan di atas sesungguhnya dapat dibaca secara tunggal. Bahwa kasus terkait pendirian rumah ibadat pada sejatinya adalah kasus kontestasi agama-agama, terkait penyiaran agama-agama. Keberadaan masjid dan gereja, misalnya, adalah simbol eksistensi dan lebih jauh dominasi agama tertentu atas demografi keagamaan. Maka ketika dalam banyak kasus rumah ibadat diketahui terdapat penolakan dari pihak tertentu, sejatinya pihak tertentu tersebut merasa khawatir dengan penyiaran agama

\footnotetext{
${ }^{1}$ Kajian Badan Litbang dan Diklat Kementerian Agama menemukan setidaknya ada 11 faktor keagamaan dan 4 faktor non-keagamaan yang dapat mengganggu kerukunan umat beragama, hasil kajian empirik lapangan. Diantara faktor keagamaan adalah penyiaran agama dan bantuan keagamaan luar negeri. Atho Mudzhar, Merayakan Kebhinnekaan Membangun Kerukunan (Jakarta: Badan Litbang dan Diklat Kementerian Agama, 2013), 106-110.

2 Sebagai contoh, CRCS mencatat terdapat 18 kasus rumah ibadat pada 2009, yang meningkat menjadi 39 kasus di 2010. The Wahid Institute mencatat pada 2010 terjadi 28 kasus pelang-garan dan 34 tindakan intoleransi terhadap rumah ibadat (total 62 kasus), yang meningkat dari jumlah kasus tahun 2009. SETARA Institute juga mencatat peningkatan, dimana pada 2010 mencatat 59 tempat ibadat yang mengalami gangguan dalam beragam bentuk. Sedangkan Moderate Muslim Society mencatat dari 81 kasus intoleransi pada 2010, yang $80 \%$ diantaranya adalah aksi penyerangan, penolakan rumah ibadat. Selanjutnya dapat dilihat pada laporan tahunan masing-masing LSM tersebut (lihat Daftar Pustaka).

${ }^{3}$ Misalnya isu Kristenisasi di Jawa Barat dan/atau Islamisasi di Papua, telah banyak menghiasi pemberitaan di negara kita. Demikian juga muncul lembaga-lembaga anti pemurtadan, dsb, yang menguatkan adanya gejala konfliktual tersebut.
}

kelompok itu dan 'tarikan' yang dimungkinkannya.

Sidney Jones dalam laporannya tentang "Kristenisasi dan Intoleransi" ${ }^{4}$ di Indonesia seakan mengamini pendapat di atas. Jones berpendapat bahwa intoleransi beragama yang meningkat di Indonesia adalah sebagai akibat 'pertarungan aksi-reaksi' antara hardline Islamists dan Christian evangelicals dalam wilayah penyiaran agama yang sama. Dengan kata lain, upaya Islamisasi dan Kristenisasi oleh para fanatikus agama di kedua pihak menimbulkan gesekan atau pertentangan dalam bentuk sikap-sikap terkategori intoleran.

Penyiaran agama sendiri sesungguhnya keniscayaan dalam praktik beragama oleh kelompok-kelompok agama. Ia merupakan perangkat dalam penyebaran agama sebagaimana diperintahkan ajaran agama. ${ }^{5}$ Selain itu, secara sosiologis penyiaran agama juga berfungsi sebagai mekanisme mempertahankan eksistensi suatu kelompok agama atau memperluas kekuasaan pengaruh suatu agama. Permasalahannya adalah ketika praktik atau proses penyiaran agama itu dilakukan tidak sebagaimana mestinya. Bahwa penyiaran agama di agama manapun sejatinya mengajarkan kebaikan, kasih sayang sesama, melarang kemunkaran, melarang berbohong, dan seterusnya. Hanya saja, hal-hal baik ini terkadang bergeser pada semangat 'rekrutmen' keanggotaan agama, kompetisi jumlah pemeluk antaragama, yang pada titik tertentu mengarah pada terganggunya kerukunan antarumat beragama.

Jika sudah menyangkut kerukunan antarumat beragama, wilayah eksternuum dan sosiologis agama, Pemerintah memiliki kewenangan dan kewajiban untuk ikut terlibat menjaga lalu lintas hubungan antarumat beragama. Sejumlah regulasi memang telah diterbitkan oleh Pemerintah pada masanya,

\footnotetext{
${ }^{4}$ Laporan Asia Briefing No. 114, Indonesia: "Christianisation" and Intolerance, yang diterbitkan International Crisis Group, sebuah lembaga kajian kebijakan antarnegara berpusat di Brussel, yang dirilis pada 24 November 2010.

${ }^{5}$ Terutama dalam agama-agama misi, ihwal penyebaran atau penyiaran agama memang diperintahkan secara tekstual dalam kitab sucinya. Dalam Islam misalnya ada kalimat " $u d$ 'uu ilaa sabiili rabbika..." (QS. An-Nahl:125), dan dalam Kristen ada perintah"Pergilah ke seluruh dunia dan beritakanlah injil kepada segala makhluk" (Kitab Markus:15), contoh landasan teologis penyebaran agama-agama ini.
} 
menjawab dinamika yang dihadapinya. Berikut penyiaran agama sepanjang sejarah Indonesia selengkapnya rangkaian kronologis pengaturan (tabel 1).

Tabel 1.

Sejumlah Instrumen Pengaturan terkait Penyiaran Agama di Indonesia ${ }^{6}$

${ }^{6}$ Diolah dari Weinata Sairin, Himpunan Peraturan di Bidang Keagamaan (Jakarta: BPK Gunung Mulia, 1994), dan Kompilasi Peraturan Perundang-undangan dan Kebijakan Kehidupan Beragama (Jakarta: Puslit-bang Kehidupan Keagamaan, 2011). 
Dari data di atas, tampak bahwa problem penyiaran agama banyak terjadi di Indonesia pada sekitar tahun 1970-an akhir dan 1980-an awal. Hal ini terlihat dari tahun-tahun penerbitan peraturan tersebut. Setelah periode itu belum ada lagi regulasi baru yang terbit, baik merevisi atau melengkapinya. Adapun secara substansial, rentetan peraturan itu melingkupi dua hal, yakni terkait penyiaran agama dan bantuan keagamaan dari luar negeri, dua hal yang pada masanya memang menjadi permasalahan di masyarakat.

Dewasa ini problem penyiaran agama dan bantuan luar negeri memang tidak terlalu menonjol ke permukaan, namun sesungguhnya ada permasalahan laten terkait penyiaran (dan kontestasi) agama, yang ditengarai berkelindan dengan kasus-kasus seputar rumah ibadat. Bahwa berbagai kasus penolakan pendirian rumah ibadat, dalam tingkat dan kasus tertentu, bersinggungan dengan 'persaingan' antaragama dalam mempertahankan umat dan merekrut umat lainnya. Karena kehadiran suatu rumah ibadat memberi kesan adanya pemeluk agama bersangkutan di sekitarnya, dan dipandang sebagai sentra penyiaran agama.

Mencermati kondisi di atas, menjadi sangat penting untuk melakukan penelitian terhadap dinamika penyiaran agama oleh agama-agama. Sebagai bentuk antisipasi atas potensi meletupnya kasus terkait penyiaran agama.

Berdasarkan gambaran di atas, maka teridentifikasi permasalahan penelitian, yakni: bagaimana pelaksanaan regulasi tentang penyiaran agama saat ini. Lalu, disusun sejumlah pertanyaan penelitian sebagai berikut: (1) Bagaimana praktik penyiaran agama dan bantuan keagamaan luar negeri-sebagai implementasi SKB No. 1 Tahun 1979?; dan (2) Apa saja faktor pendukung dan penghambat implementasi SKB dimaksud?

Tujuan penelitian ini adalah untuk mengetahui praktik penyiaran agama dan bantuan keagamaan luar negeri di lapangan dewasa ini. Selain itu, bertujuan untuk mengetahui faktor-faktor pendukung dan penghambat implementasi SKB dimaksud.

Hasil penelitian ini diharapkan dapat bermanfaat bagi Kementerian Agama dan Kementerian Dalam Negeri dalam merumuskan bahan kebijakan terkait penyiaran agama, persisnya revisi atas SKB No. 1 Tahun 1979 yang dinilai banyak pihak telah out of date di tengah perkembangan masyarakat beragama. Secara akademis, hasil kajian ini diharapkan memperkaya bahan kajian terkait hubungan antaragama.

\section{B. Kajian Terdahulu}

Penelitian ini sejatinya melanjutkan kajian terdahulu oleh Puslitbang Kehidupan Keagamaan yang merekam pandangan masyarakat tentang praktik penyiaran/dakwah agama di sepuluh lokasi pada delapan provinsi di Indonesia, tahun 2007. Penelitian yang berjudul "Pandangan Masyarakat terhadap Penyiaran/Dakwah Agama" itu antara lain menyimpulkan bahwa para penyiar agama pada umumnya belum banyak mengetahui materi pasal 3 dan 4 SKB 1979 tentang Penyiaran Agama. Selain itu, ditemukan di beberapa daerah masih adanya praktik-praktik penyiaran agama yang dilakukan dengan cara penyebaran pamflet, majalah, dan bujukan ke rumah-rumah umat beragama lain. Sesuatu kondisi yang rawan bagi kondusivitas kerukunan antarumat beragama. Meski demikian, di daerah lainnya penyiaran agama ternyata telah didasari oleh semangat pluralitas dan kekeluargaan. ${ }^{7}$

Penelitian oleh lembaga yang sama pada 2010, melihat praktik penyiaran agama khusus dalam Islam. Dari penelitian tentang gerakan dakwah di kalangan umat Islam ini terungkap adanya modus penyiaran antaragama yang juga rawan mengganggu kerukunan beragama. Penyiaran itu berupa kegiatan sosial dan kemanusiaan di daerah Jawa Barat yang ditengarai bernuansa pemurtadan, yang meskipun belum sampai menimbulkan konflik terbuka namun tetap rawan ke arah konflik. ${ }^{8}$

Sementara itu, kajian tahun 2011 di Kecamatan Panakukang, Kota Makassar, ternyata menunjukkan bahwa sebagian besar informan (dalam hal ini para penyuluh agama) telah mengetahui keberadaan dan manfaat SKB No. 1 Tahun 1979 ini bagi kerukunan. Memang juga

\footnotetext{
${ }^{7}$ Bashori A. Hakim dan Titik Suwaryati, (Ed.), Pandangan Masyarakat terhadap Penyiaran/Dakwah Agama (Jakarta: Puslitbang Kehidupan Keagamaan, Badan Litbang dan Diklat Kementerian Agama, 2007).

8 Yusuf Asry, (Ed.), Gerakan Dakwah Islam dalam Perspektif Kerukunan Umat Beragama (Jakarta: Puslitbang Kehidupan Keagamaan, Badan Litbang dan Diklat Kementerian Agama, 2012).
} 
ditemukan ada sebagian kecil penyuluh agama yang belum mengetahuinya, yang berakibat pada praktik penyiaran agamanya yang kadangkala menyinggung agama lain sehingga mengundang kerawanan sosial tertentu. ${ }^{9}$

Demikian diantara kajian terkait. Adapun distingsi dan fokus penelitian ini adalah pada praktik penyiaran agama oleh lembaga/kelompok keagamaan terkait dengan implementasi SKB tahun 1979, lebih bersifat evaluatif perkembangan mutakhir. Karenanya, penelitian ini menjadi penting untuk melengkapi dan memperbaharui informasi dari penelitian sebelumnya.

Secara konseptual, penyiaran agama ada di ranah sosiologis, bukan teologis. Karenanya, Pemerintah bisa dan berwenang melakukan pengaturan agar proses/praktik penyiaran agama oleh masing-masing kelompok agama itu berjalan dengan baik, sehingga ketertiban umum dan kerukunan umat beragama dapat terwujud. Sejauh ini, regulasi terkait penyiaran agama adalah SKB No. 1 Tahun 1979. Selain itu, belum ada lagi regulasi baru meski tantangan ketidakrukunan akibat penyiaran agama (baca: kontestasi dan kompetisi agama) semakin besar. Selain karena dinamika masyarakat di era demokratis, juga karena perkembangan teknologi dan media komunikasi yang sangat pesat.

Untuk merevisi ataupun menyusun regulasi baru, Pemerintah perlu melihat dan mengevaluasi pelaksanaan regulasi lama tersebut (SKB 1/1979). Selain sebagai dasar pijakan, juga untuk menemukan sisi lemah dari regulasi yang ada ini. Respon masyarakat menjadi kunci untuk mengevaluasi implementasi SKB karena praktik penyiaran terjadi di masyarakat, dan bahkan mereka sekaligus sebagai subjeknya.

Berdasarkan alur pikir tersebut, penelitian ini akan dilakukan. Mengevaluasi pelaksanaan/ implementasi substansi SKB dengan mendengar respon masyarakat dan melihat fakta-fakta lapangan terkait hal itu, sebagaimana studi evaluasi perundang-undangan. Menguji 'substansi' SKB lebih dipilih dibandingkan menguji 'bunyi' pasal-pasal SKB, karena diasumsikan banyak masyarakat yang tidak tahu butir SKB atau bahkan tidak tahu eksistensi SKB

\footnotetext{
${ }^{9}$ Muchith, A. Karim, "Penyiaran Agama dalam Perspektif Islam dan Kristen di Panakkukang, Kota Makassar", dalam Harmoni, Volume X Nomor 2 April-Juni 2012.
}

1/1979 itu sendiri, namun secara substansial sesungguhnya mereka mengetahui adanya larangan dan perintah sebagaimana isi dimaksudkan oleh SKB dimaksud.

Masyarakat yang dimaksud adalah kalangan tokoh agama dan simpul-simpul kelompok agama, yang secara sederhana dapat dipahami bersingggungan dengan persoalan penyiaran agama. Termasuk dalam hal ini adalah ormas keagamaan, sebagaimana dalam kajian ini salahsatunya akan berfokus pada profil dan peran dakwah ormas Wahdah Islamiyah.

Penyiaran agama sendiri yang dimaksudkan adalah segala upaya dalam mendiseminasikan ajaran agama, baik pembinaan ke dalam secara internal maupun ekspansi ke luar kalangan agama bersangkutan. Adapun kerukunan umat beragama, merujuk pada definisi pada PBM No. 9 dan 8 Tahun 2006, adalah keadaan hubungan sesama umat beragama yang damai dilandasi toleransi, saling pengertian, saling menghormati, menghargai kesetaraan dalam pengamalan ajaran agamanya dan kerjasama dalam kehidupan masyarakat, berbangsa dan bernegara.

\section{Metode Penelitian}

Penelitian dengan pendekatan kualitatif ini mengumpulkan data dengan studi kepustakaan/ dokumentasi, wawancara, dan pengamatan lapangan (observasi). Studi kepustakaan dilakukan dengan mengkaji referensi terkait, baik berupa buku, dokumen kebijakan/regulasi, maupun informasi lain dari dunia maya. Wawancara dilakukan dengan sejumlah informan kunci di Kota Makassar, Sulawesi Selatan, antara lain adalah: pejabat pada Kantor Kementerian Agama, Kesbangpolinmas, FKUB, majelis agama, dan ormas keagamaan. Sedangkan observasi dilakukan langsung ke titik-titik penting yang mendukung penelitian ini.

Data kemudian dinalisis secara deskriptifanalitik, melalui tahap-tahap editing, klasifikasi data, reduksi data, dan interpretasi untuk memperoleh kesimpulan. Interpretasi data dalam upaya analisis dilakukan dengan bantuan teori sosial terkait. Untuk menguji keabsahan data, digunakan teknik triangulasi dengan cara pemeriksaan melalui sumber-sumber lain. Menurut Patton (1987) triangulasi dengan sumber berarti membandingkan dan mengecek balik derajat keterpercayaan suatu informasi 
melalui waktu dan alat yang berbeda. ${ }^{10}$ Triangulasi misalnya dilakukan dengan mengecek data/informasi tertulis dengan wawancara, ataupun mengecek suatu informasi dari pejabat tertentu dengan informasi dari perwakilan ormas.

Penelitian ini dilakukan di Kota Makassar, yang dipilih karena memiliki tingkat heterogenitas dan mobilitas sosial yang cukup tinggi, sehingga diasumsikan memiliki tingkat interaksi antaragama yang cukup intens. Pengumpulan data lapangan dilakukan total selama 16 hari, yakni pada tahap penjajakan tanggal 24 hingga 28 April 2013, dan dilanjutkan pada pengumpulan data tanggal 21 hingga $31 \mathrm{Mei}$ 2013.

\section{Temuan dan Pembahasan}

Luas wilayah Kota Makassar, Ibukota Sulawesi Selatan, tercatat $175,77 \mathrm{~km}$ persegi yang meliputi 14 kecamatan. Secara administratif kota ini terbagi atas 14 kecamatan, 143 kelurahan, 980 RW dan 4.867 RT. Pada tahun 2011, penduduknya tercatat sebanyak 1.352 .136 jiwa yang terdiri dari 667.681 laki-laki dan 684.455 perempuan. Hal ini menunjukkan peningkatan jumlah penduduk dari tahun sebelumnya yang tercatat sebanyak 1.339.374 jiwa.

Secara ekonomi, Kota Makassar merupakan kota industri penting dengan tingkat perekonomian yang maju. Cerminan kemajuan ekonomi daerah itu antara lain ditunjukkan oleh Pendapatan Domestik Regional Bruto (PDRB) kota ini yang cukup tinggi. Sebagai kota pelabuhan dan transit, serta tujuan penyelenggaran acara-acara berlevel dunia, Kota Makasar menjadi kota perekonomian penting.

Sementara itu, Kota Makassar juga memiliki SDM yang cukup baik. Jenjang pendidikan yang tersedia sangat luas, serta upaya peningkatan SDM yang cukup baik, menjadikan Kota Makassar kota dengan kualitas SDM yang baik. Banyak tokoh-tokoh nasional lahir dan dibesarkan di kota ini. Pada tahun 2011/2012 di Kota Makasar, jumlah Sekolah Dasar sebanyak 462 unit dengan jumlah guru sebanyak 6.586

\footnotetext{
${ }^{10}$ Lexy J. Moleong, Metodologi Penelitian Kualitatif (Bandung: PT Remaja Rosdakarya, 2002), 178.
}

orang dan jumlah murid sebanyak 152.200 orang. Jumlah SLTP sebanyak 179 unit dengan jumlah guru sebanyak 3.976 orang dan jumlah murid sebanyak 61.107 orang. Jumlah SLTA 117 unit dengan jumlah guru sebanyak 4.164 orang dan jumlah murid sebanyak 52.046 orang.

Selain dikenal sebagai kota para saudagar, Makassar juga dikenal sebagai kota dengan masyarakat yang agamis dan berbudaya. Menilik sejarahnya, perkembangan agama-agama di Kota Makassar, khususnya agama Islam yang dibawa para raja-raja di masanya, cukup mewarnai gambaran masyarakat religius saat ini. Di samping itu, budaya orang Makassar yang menjunjung nilai-nilai agama berkelindan dan sinergis menjadikan masyarakat Makassar sebagai pemegang adat yang baik, sekaligus umat beragama yang taat. Misalnya dikatakan Nurman Said:

"Kesetiaan terhadap pangadakkang dalam bentuk kepatuhan menjalankan ketentuanketentuan adat dalam pengertian luas masih mendapat perhatian besar di kalangan orangorang Makassar. Kesadaran untuk memelihara harga diri sebagai makhluk ciptaan Tuhan yang bermartabat mengharuskan orang-orang Makassar berusaha sekuat tenaga untuk menegakkan siri' sepanjang kehidupan mereka. Usaha-usaha yang mendukung pemeliharaan siri' di kalangan orang-orang Makassar merupakan hal yang sangat diutamakan. Bersamaan dengan itu, emosi keagamaan mereka termasuk sangat menonjol sebagaimana terlihat pada nuansa keagamaan yang mewarnai aktivitas kehidupan mereka sehari-hari. Kegiatan-kegiatan upacara adat baik dalam skala terbatas dalam keluarga sampai kepada yang berskala luas dalam masyarakat selalu diwarnai oleh semangat keagamaan. Atas dasar ini maka tidak berlebihan jika dikatakan bahwa orang-orang Makassar, pada umumnya, merupakan satu komunitas yang sangat taat menjalankan ketentuan-ketentuan adat serta memiliki fanatisme keagamaan yang sangat kuat."11

Jika melihat komposisi kependudukan, masyarakat Kota Makassar mayoritas beragama

\footnotetext{
${ }^{11}$ Nurman Said, Masyarakat Muslim Makassar: Studi tentang Pola-pola Integrasi Sosial antara Muslim Pagama dengan Muslim Sossorang (Yogyakarta: UIN Sunan Kalijaga, Disertasi, 2007), 70-71.
} 
Islam, bahkan hingga mencapai 90\%. Meski demikian, kehidupan masyarakat kota yang heterogen menjadikan kehidupan beragama masyarakatnya kian dinamis. Berikut selengkapnya komposisi penduduk Kota Makassar berdasarkan agama, serta jumlah rumah ibadat dan rohaniawan (Tabel 2).

Tabel 2. Data Pemeluk, Rumah Ibadat, dan Rohaniawan di Kota Makassar 2012

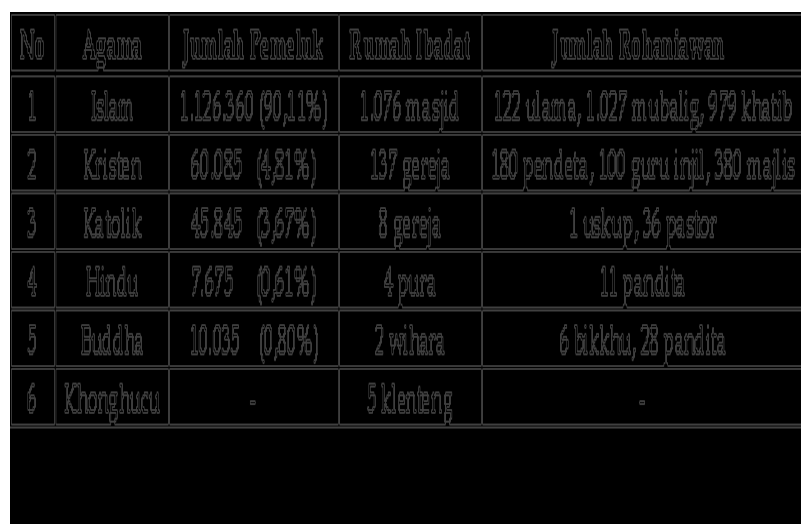

Kementerian Agama Kota Makassar 2011.

Agama-agama terus berkembang dengan berbagai upaya penyiaran dengan sejumlah tenaga penyiaran agama (baca: penyuluh agama). Data pada Kementerian Agama Kota Makassar, jumlah penyuluh agama PNS di Kota Makassar seluruhnya 48 orang, sedangkan yang non-PNS berjumlah 197 orang.

Penyiaran Agama kepada Pemeluk Agama Lain

SKB No. 1 Tahun 1979 melarang adanya penyiaran agama kepada pemeluk agama lain, pertama, dengan menggunakan bujukan dengan atau tanpa pemberian barang, uang, pakaian, makanan dan atau minuman, pengobatan, obatobatan dan bentuk-bentuk pemberian apapun lainnya agar orang atau kelompok orang yang telah memeluk/menganut agama yang lain berpindah dan memeluk/menganut agama yang disiarkan tersebut. Kedua, SKB melarang penyebaran agama kepada pemeluk agama lain, dengan cara menyebarkan pamflet, majalah, buletin, buku-buku, dan bentuk-bentuk barang penerbitan cetakan lainnya kepada orang atau kelompok orang yang telah memeluk/menganut agama yang lain. Serta ketiga, dengan cara melakukan kunjungan dari rumah ke rumah umat yang telah menganut agama yang lain. Halhal itu dapat memicu terjadinya konflik antara pemeluk kedua agama tersebut

Pada umumnya, dari semua informan yang ditemui menyatakan bahwa di Makassar belakangan ini tidak ada praktik penyiaran agama dengan bujukan, rayuan, atau pendekatan tertentu secara terbuka. Setidaknya hal ini sebagaimana terdengar atau terlihat di permukaan oleh para informan. Misalnya dikatakan Kepala Kementerian Agama Kota Makassar, sebagai pihak yang otoritatif bicara soal agama. Dikatakannya, saat ini tidak ada lagi upaya-upaya penyiaran agama kepada orang yang sudah beragama dengan cara-cara bujukan pemberian sesuatu materi. Memang, diceritakannya, di masa lalu dikabarkan pernah terjadi upaya pengalihagamaan melalui bantuan dan bujukan materi tertentu. Kejadiannya terjadi di luar Kota Makassar, yakni di sebuah perkampungan di Gowa. Modusnya, orang-orang Kristen yang kaya membeli tanah-tanah di perkampungan Gowa yang mayoritas masyarakatnya muslim. Mereka membuat toko-toko dan mempekerjakan orang-orang setempat yang muslim dan kebetulan dari kalangan bawah secara ekonomi. Lalu, sang majikan banyak memberikan bantuan dan konon secara perlahan memberikan arahan agar sang pegawai mau berpindah agama. Kasus ini telah ditangani oleh Kementerian Agama, dan cara-cara ini dapat dicegah pada masa itu. Kementerian Agama sendiri, khususnya di Kota Makassar, lebih memerankan penyuluh agama untuk menangkal upaya-upaya semacam itu yang rawan bagi kerukunan umat beragama. Melalui praktik ilmu intelijen dasar, yakni 'menyamar' seolah-olah bukan aparat dan mubalig, penyuluh agama memastikan prosesproses penyiaran agama di dalam masyarakat dapat terpantau dan terhindar dari penggunaan cara-cara yang tidak semestinya. Setiap penyuluh agama yang sudah dibagi tanggungjawab kewilayahan, melakukan pemantauan dan upaya penyuluhan agar tidak terjadi kasus-kasus keagamaan di wilayahnya. Baik kasus semacam aliran yang melakukan penyimpangan, ataupun terkait penyiaran agama. ${ }^{12}$

Demikian halnya dalam amatan Kesbangpolinmas Kota Makassar, instansi yang juga bertanggung jawab atas kondisi harmoni

${ }^{12}$ Wawancara dengan AW, Kankemenag Kota Makassar, 22 Mei 2013. 
sosial politik di wilayah ini. Dikatakan, belum pernah ada informasi ataupun laporan mengenai kasus penyebaran agama kepada umat beragama lain dengan bujukan ataupun rayuan materi tertentu. Dengan perangkat intelijen yang dimilikinya (juga dalam rapat-rapat Komunintas Intelijen Daerah/Kominda), sejauh ini belum pernah ada laporan dari masyarakat atau sekadar informasi tentang kasus terkait penyiaran agama itu. ${ }^{13}$

Kalangan majelis dan ormas keagamaan pun menyatakan belakangan ini tidak ada lagi upaya penyiaran agama dengan cara-cara bujukan pemberian materi seperti itu. MUI Kota Makassar menyatakan tidak ada lagi praktik penyiaran semacam itu. Demikian juga pemuka agama Katolik dan Kristen, mereka mengatakan tidak ada lagi upaya penyebaran agama dengan caracara bujukan atau pemberian tertentu. Memang diakui di masa lalu pernah ada, misalnya dengan cara bantuan sosial bagi masyarakat atau pengobatan. Perwakilan dari FKUB Kota Makassar juga menyatakan hal yang serupa, saat ini tidak ada lagi informasi tentang penyiaran agama dengan cara-cara yang berpotensi mengganggu kerukunan itu. ${ }^{14}$

Dari pendapat-pendapat di atas, tampak bahwa untuk masa sekarang ini di Makassar tidak ada lagi upaya penyiaran atau penyebaran agama kepada orang yang sudah beragama melalui cara-cara bujukan, pengobatan gratis, atau dengan pemberian materi tertentu. Meski demikian, dalam perkembangannya, ada informasi lain yang cukup 'lantang' beredar di dunia maya. Informasi itu memberitakan adanya indikasi upaya pemurtadan di dalam masyarakat Kota Makassar dan telah mendapat respon banyak pihak. Sebuah artikel di laman VOAIslam, misalnya, menampilkan judul yang cukup bombastis dan provokatif tentang ini, yakni: "Selamatkan! Makassar Terancam Kristenisasi Berkedok Pengobatan Gratis." Dalam laman yang diunggah pada 17 Agustus 2013 ini diberitakan bahwa pada tanggal 21-24 Agustus 2013 akan ada kegiatan pemurtadan berkedok pengobatan gratis di Lapangan Karebosi, Makassar, oleh Pendeta

\footnotetext{
${ }^{13}$ Wawancara dengan Ams, Waka Kesbanglinmas Kota Makassar, 23 Mei 2013.

${ }^{14}$ Diskusi pendalaman pada acara FGD di Kantor Kementerian Agama Kota Makassar 30 Mei 2013.
}

Dr. Peter Youngren asal Amerika Serikat. Meski belum bisa dibuktikan benar tidaknya terjadi upaya "pemurtadan" (pengalihagamaan) sebagaimana ditakutkan itu, namun informasi yang beredar via BBM ini memang dalam perkembangannya cukup mendorong Pemkot Kota Makassar mencabut izin acara ini. Setelah melalui rapat terpadu Musyawarah Pemimpin Daerah (Muspida) pada 19 Agustus 2013, Pemerintah Kota Makassar akhirnya mencabut izin rencana acara Festival Persahabatan oleh pendeta asal Amerika Serikat, Dr. Peter Youngren, yang berupa pengobatan gratis tersebut. Alasannya demi kepentingan yang lebih besar, yakni menghindari terjadinya gejolak yang berpotensi mengganggu kondisi keamanan dan agar tetap kondusif. Keputusan Pemkot Makassar itu dilakukan atas dasar kepentingan yang lebih besar, yakni menghindari terjadinya gejolak yang berpotensi mengganggu kondisi keamanan dan agar tetap kondusif. Bersama dengan pelarangan pelaksanaan kegiatan acara di tempat terbuka ini, Pemkot juga menyarankan kepada panitia untuk memindahkan acara tersebut di tempat tertutup atau di rumah ibadah. ${ }^{15}$

Di dalam lingkungan Kota Makassar yang secara demografis mayoritas beragama Islam dan berkarakter agamis-taat ini, isu pemurtadan dan kristenisasi memang akan cukup cepat membesar gaung dan responnya. Hal ini sejatinya dapat dipahami, sebagaimana isu Islamisasi juga akan cepat terrespon di tengah umat mayoritas Kristen di Papua atau mayoritas Katolik di NTT, misalnya. Gerakan penyiaran kalangan minoritas akan mendapat respon yang cepat dari kalangan agama dominan di tempat itu. Sebaliknya, upaya penyiaran agama kalangan mayoritas di suatu daerah akan lebih direspon biasa saja atau bahkan lebih permisif dan didukung. Dalam konteks Makassar yang mayoritas Islam, upaya penyiaran, dakwah, atau pengislaman, diresponi oleh masyarakat secara positif dan mendapat dukungan atau ekspose memadai. Sebagai contoh, di Masjid Al Markaz Al Islamy Makassar, hampir setiap hari Jumat ada prosesi pengislaman (syahadah) yang ditunjukkan secara demonstratif

\footnotetext{
${ }^{15}$ Baca "Pemkot Makassar Larang Pengobatan Gratis dari Seorang Pendeta", dalam laman www.indonesia.ucan-news.com/ 2013/08/20/pemkot-makassar-larang-pengobatan-gratis-dariseorang-pendetal diunduh pada 30 September 2013.
} 
di hadapan jemaah shalat Jumat. Selain sebagai bentuk pengumuman dan menjadi wahana penguatan iman bagi sang mualaf dan jamaah pada umumnya, prosesi ini di sisi lain juga dapat memberi kesan "keberhasilan" proses dakwah, Islamisasi. ${ }^{16}$

Sementara itu, penyebaran agama dengan cara penyebaran pamflet, majalah, buletin, bukubuku, dan barang cetakan lainnya kepada umat agama lain, tidak terjadi atau setidaknya tidak secara vulgar dilakukan. Baik kalangan aparat Pemerintah maupun kalangan pemuka agama menyatakan hal-hal seperti itu tidak terjadi atau mengemuka di masyarakat. Jikapun ada selebaran, buletin, atau buku-buku keagamaan yang bersifat penyiaran agama, selalu dibuat dengan target "untuk kalangan sendiri" atau untuk kalangan umat agama bersangkutan. Namun demikian, observasi peneliti di lapangan, ditemukan juga adanya "upaya yang terindikasi sengaja" untuk menyediakan bacaan bernuansa penyiaran agama tertentu yang disimpan di tempat-tempat yang diharapkan dibaca pemeluk agama lain. Meski bentuk dan sampulnya terkesan majalah umum, namun ketika dibuka dan dibaca terasa sekali unsur penyiaran agamanya. ${ }^{17}$ Hanya saja, tidak terdengar ada respon berlebihan dari kalangan masyarakat atas upaya terselubung semacam ini.

Adapun mengenai penyiaran agama dengan

${ }^{16}$ Hingga penelitian dilakukan telah ada 2.873 orang mualaf yang diislamkan di hadapan ribuan jemaah Jumat Masjid AlMarkaz ini. Alasan masuk Islam rata-rata atas kehendak sendiri, atau karena alasan mau menikahi pasangan yang muslim. Menurut pengurus Al-Markaz, pihaknya hanya melayani/menerima (secara pasif) siapapun yang ingin diislamkan di masjid besar ini. Tidak ada upaya dakwah tersendiri untuk mengislamkan ini. Wawancara dengan Sdri. T, pengurus bagian mualaf Masjid AlMarkaz Al-Islami pada 24 Mei 2013.

${ }^{17}$ Pengalaman/observasi peneliti sendiri ketika menginap di Hotel X di kota ini, ditemukan ada sebuah majalah kecil yang disimpan di meja kecil di samping kasur tidur. Majalah dengan sampul dan headline seperti majalah motivasi ini, ketika isengiseng dibaca isinya ternyata berisi tentang testimoni pemelukan agama, berita tentang aktivitas organisasi aliran agama tertentu, dan artikel penyiaran agama. Ketika penulis coba simpan ke dalam laci, besok paginya setelah kamar dibereskan, majalah kembali ke tempatnya, di atas meja kecil yang 'mengundang' mata tamu untuk melihat dan membaca-nya. Dalam kasus lain ekspose sejumlah majalah populer keagamaan di ruang-ruang publik cukup marak, dan ini fenomena umum. Sebagaimana diketahui, pascareformasi dan pascakebebasan pers, telah bermunculan majalah-majalah keagamaan yang tidak dapat dipungkiri bermuatan penyiaran agama-bahkan ada yang terkesan 'menyerang' pihak lain. Majalah-majalah itu dijual secara terbuka di mall, pasar, hingga pinggir jalan. mengunjungi rumah ke rumah, diakui perwakilan Kristen hal tersebut masih ada di kalangan Kristen terutama yang dilakukan oleh kelompok Saksi Yehova. ${ }^{18}$ Bagi kalangan Kristen sendiri kelompok ini memang cukup mengkhawatirkan, karena kerap menggarap jemaat dari kelompok Kristen lain, dan karenanya tidak jarang terjadi gesekan antardenominasi.

\section{Bantuan Luar Negeri kepada Lembaga Keagamaan}

Bantuan keagamaan luar negeri, sebagaimana ditegaskan di dalam SKB No.1 Tahun 1979, adalah segala bentuk bantuan yang berasal dari luar negeri yang berwujud bantuan tenaga, barang dan/atau keuangan, fasilitas pendidikan, dan bentuk bantuan lainnya yang diberikan oleh Pemerintah Negara Asing, organisasi, atau perseorangan di luar negeri kepada lembaga keagamaan dalam rangka pembinaan, pengembangan dan penyiaran agama di Indonesia. Di dalam Pasal 6 SKB ini dinyatakan bahwa segala bentuk usaha untuk memperoleh dan/atau penerimaan bantuan luar negeri dilaksanakan dan melalui persetujuan Panitia Koordinasi Kerjasama Teknik Luar Negeri (PKKTLN) setelah mendapat rekomendasi dari Kementerian Agama.

Terkait bantuan keagamaan dari luar negeri untuk lembaga keagamaan tidak selalu mudah untuk diungkap. Hal yang merupakan "rahasia dapur" di lembaga/institusi keagamaan ini, cenderung dianggap sensitif dan pantang untuk diinformasikan. Sejauh informasi yang didapat dari aparat terkait (Pemda dan Kementerian Agama setempat), hingga penelitian ini dilakukan, tidak satupun ada laporan dari lembaga keagamana atas bantuan luar negeri yang mungkin mereka terima. Pemerintah sendiri 'enggan' untuk menanyakan karena khawatir dimaknai sebagai ingin mendapat bagian atau jatah tertentu. Karenanya, meski diketahui banyak rumah-rumah ibadat yang berdiri megah, atau sekolah-sekolah keagamaan yang mewah, lalu diasumsikan mendapat bantuan dari pihak asing, namun Pemerintah setempat tidak pernah bertanya: dari mana dana pembangunan rumah ibadat ini, misalnya. Bahkan ketika salah seorang

${ }^{18}$ Disampaikan Kasi Kristen Kanwil Agama, wawancara pada 22 Mei 2013, juga disampaikan perwakilan PGI Kota Makassar dalam FGD pada 30 Mei 2013. 
pejabat Pemerintah ikut meresmikan rumah ibadat atau sekolah bersangkutan.

Di kalangan Kristen, dijelaskan Pendeta A, bahwa kalau tahun 1970-1980an memang banyak gereja mendapat bantuan dari luar negeri. Hal ini juga yang antara lain menyebabkan adanya SKB ini. Namun sejak tahun 1990 -an sudah tidak ada lagi bantuan finansial untuk bangunan fisik, apalagi untuk biaya gaji. Jikapun adanya sekarang hanya bantuan program, itupun dalam bentuk proposal. Bantuan program itu bisa berasal dari gereja di luar negeri (Amerika, Jerman, dan lain-lain), bisa dari NGO, bisa juga dari atas nama perorangan. Namun pada umumnya sekarang bantuan-bantuan itu cukup terbuka, bahkan harus dipastikan akuntabilitasnya oleh akuntan publik. Di kalangan Katolik saat ini memang ada bantuan dari luar negeri (yakni NGO di Jerman), yang jumlahnya hanya Rp 50 juta. Bantuan program ini digunakan untuk pelatihan kader lintas agama, pemuda dan perempuan. ${ }^{19}$

Demikian halnya di kalangan muslim, sebagaimana antara lain dijelaskan seorang pengurus ormas keagamaan Wahdah Islamiyah, bahwa tidak ada bantuan finansial dari luar negeri untuk pembangunan fisik atau menggaji pegawai di lembaganya. Lembaga yang cukup maju dalam pendidikan dan dakwahnya ini menghidupi organisasi dan pegawainya dari usaha-usaha yang dilakukannya, semisal dari lembaga pendidikan, toko buku, ataupun toko yang dimilikinya. Selain itu ada juga sedekah atau infaq yang dikumpulkan dari anggotanya yang dikumpulkan secara rutin dan tertib. Memang ada juga bantuan 'alakadarnya' dari tamu-tamu dari luar negeri (misalnya Arab Saudi atau Madinah) yang ketika berkunjung ke suatu masjid di Makassar dan mengeluarkan infaq untuk membantu pembangunan masjid tersebut. ${ }^{20}$

Demikianlah, kecurigaan pihak tertentu tentang bantuan dari negara-negara di Barat ke sejumlah gereja, atau bantuan dari negara-negara Arab untuk sejumlah masjid, harus berhenti pada asumsi, sulit dibuktikan. Meski demikian, sebagaimana diungkap salah seorang narasumber, bahwa ada banyak jalan untuk menyiasati masuknya bantuan luar negeri untuk

\footnotetext{
${ }^{19}$ Penjelasan A dan B pada FGD 30 Mei 2013.

${ }^{20}$ Wawancara dengan pengurus WI pada 27 Mei 2013.
}

lembaga-lembaga keagamaan di dalam negeri secara 'aman'. Jikapun akan ada bantuan yang diterima, tentu tidak akan menggunakan transfer via bank karena terlalu beresiko. Terlalu mudah bagi lembaga pengawasan semacam PPATK, misalnya, untuk mencurigai aliran dana besar dari luar negeri ke pihak tertentu di dalam negeri. Bisa dicurigai jaringan terorisme atau kartel bisnis tertentu, dan sebagainya. Jika bantuan dibawa by hand berupa uang tunai yang cukup besar, juga terlalu beresiko pada pintu pemerikasaan di imigrasi. ${ }^{21}$ Modus-modus yang diduga kerap dilakukan, misalnya, dalam bentuk membawa uang tunai meski tidak bisa terlalu besar, yang dibawa by hand oleh seseorang dalam kerangka berwisata ke Indonesia. Cara lain, seorang wisatawan asing yang sedang berlibur di Indonesia mengambil uang dari rekeningnya via ATM Bank di luar negeri. Ada juga yang menyampaikan bantuan itu melalui skema modal asing (PMA) untuk suatu perusahaan, padahal uang itulah yang dipakai untuk bantuan ke lembaga keagamaan.

Sejauh ini aliran dana luar negeri memang sulit tertahankan dan terdeteksi. Kementerian Luar Negeri kerap mengeluhkan adanya bantuan-bantuan untuk ormas dan lembaga dari luar negeri tanpa ada izin atau sekedar pemberitahuan ke pihaknya, sebagai lembaga resmi Pemerintah yang mengatur ihwal hubungan dengan luar negeri. ${ }^{22}$ Upaya pemantauan melalui mekanisme pelaporan akuntabilitas keuangan ormas atau lembaga masyarakat pada RUU Keormasan pun belum tentu berhasil. Ada resistensi yang cukup besar dari beberapa LSM.

\section{Penggunaan Tenaga Rohaniawan Asing}

Pasal 7 SKB No. 1 Tahun 1979 menyebutkan bahwa semua lembaga keagamaan wajib mengadakan pendidikan dan latihan bagi warga negara Indonesia untuk dapat menggantikan

\footnotetext{
${ }^{21}$ Kasus terbaru misalnya menimpa Ust. Yusuf Mansur ketika membawa uang tunai sebesar RM 1,5 juta atau sekitar Rp 4,8 miliar dalam koper, hasil pengumpulan infaq di Malaysia untuk pembangunan sarana pendidikan di pesantrennya. Beliau sempat tertahan dan dipermasalahkan ketika melewati bagian Bea Cukai Bandara Batam. Selanjutnya baca Kompas, Senin, 20 Mei 2013.

${ }^{22}$ Misalnya diungkapkan Direktur HAM dan Kemanusiaan Kemenlu pada suatu rapat tentang tindak lanjut kerja-sama hasil dialog bilateral Indonesia-Norwegia tahun 2012.
} 
tenaga-tenaga rohaniawan dan atau tenaga asing lainnya, yang melakukan kegiatan dalam rangka bantuan luar negeri. Penggunaan tenaga rohaniawan asing dan atau tenaga ahli asing lainnya atau penerimaan segala bentuk bantuan lainnya dalam rangka bantuan luar negeri dilaksanakan dengan memperhatikan ketentuan peraturan perundang-undangan yang berlaku.

Di Kota Makassar ada beberapa tenaga asing yang dipekerjakan untuk melakukan penyiaran agama. Sebagaimana diungkapkan perwakilan Katolik, bahwa saat ini ada tinggal seorang tenaga asing dan itupun sudah akan selesai, sudah tidak dapat diperpanjang izin tinggalnya. Tenaga dari Jerman yang kini menjadi dosen di salahsatu kampus di Makassar ini. Sekarang ini konon memang cukup sulit untuk mengurus izin tenaga keagamaan dari luar negeri. Jika di Indonesia memang belum ada spesifikasi bersangkutan, maka bisa jadi diperbolehkan. Namun jika kualifikasi tenaga dimaksud itu sudah ada di dalam negeri, biasanya sulit diizinkan. Belum lagi biayanya izin dan perpanjangan itu cukup mahal. Untuk memperbaiki KIM saja sekitar 1000 dollar. ${ }^{23}$ Sedangkan untuk menggantikan tenaga asing tersebut telah disiapkan tenaga-tenaga lokal dari Indonesia melalui mekanisme pendidikan di dalam negeri, baik kampus sekolah keagamaan ataupun pendidikan khusus calon pendeta.

Di kalangan muslim, tidak ada tenaga asing yang dipekerjakan untuk penyiaran agama. Jikapun di beberapa lembaga bahasa Arab ada native yang mengajar bahasa, mereka masuk sebagai dosen di dunia pendidikan. Banyak pula tenaga-tenaga lokal yang berkuliah dan sempat bermukin di luar negeri, lalu kembali ke Indonesia dan mendirikan yayasan pendidikan dan dakwah. Adapun diklat khusus untuk pengganti tenaga asing tidak dilakukan, melainkan tenagatenaga keagamaan dididik dan lahir dari kampus Islam seperti IAIN/UIN/STAIN maupun pondokpondok pesantren. ${ }^{24}$

\section{Faktor Pendukung dan Penghambat Implementasi SKB}

Upaya implementasi SKB No. 1 Tahun 1979 menghadapi sejumlah hambatan, meski juga ada sejumlah dukungan. Dari wawancara dan

\footnotetext{
${ }^{23}$ Wawancara dengan A pada 30 Mei 2013

${ }^{24}$ Wawancara dengan bagian dakwah WI, pada 27 Mei 2013.
}

observasi, diketahui diantara hal yang mendukung implementasi SKB tersebut adalah:

1. Pada hakikatnya segenap umat beragama cenderung pada semangat kerukunan, tenggang rasa, saling menghargai dan saling menghormati antara sesama umat beragama, dalam proses interaksi dan penyiaran masingmasing agama. Kecenderungan alamiah ini mendukung pada terlaksananya proses penyiaran agama yang baik, saling menghormati, dan mendukung kerukunan umat beragama.

2. Peran aktif Pemerintah daerah dan pusat dalam meresponi dan mencari solusi atas kondisi-kondisi gesekan atau konflik yang berkaitan dengan proses penyiaran agama. Respon berupa kebijakan atau regulasi, maupun respon dalam bentuk programprogram penguatan toleransi dan saling pemahaman masyarakat.

3. Modal dasar adanya hubungan antarumat beragama, baik dalam forums seperti FKUB, ataupun dalam kegiatan keseharian, mendukung terbangunnya kesalingpahaman yang berwujud pada saling menjaga dalam proses penyiaran agamanya.

Sedangkan beberapa hal yang menghambat proses implementasi SKB antara lain:

1. Lemahnya pengetahuan dan pemahaman masyarakat terhadap butir-butir atau diktum yang diatur di dalam SKB No. 1 Tahun 1979. Bahwa banyak diantara pelaku penyiaran agama belum secara baik mengetahui dan memahami aturan ini, sehingga sesekali justeru melanggar aturan ini.

2. Wacana jaminan kebebasan beragama yang berkelindan dengan jaminan kebebasan berekspresi dan mengungkapkan keyakinan sesorang, dalam tingkat tertentu berseberangan dengan implementasi SKB ini. Misalnya, kebebasan untuk menulis dan menerbitkan buku (atau sekadar buletin) yang isinya boleh jadi kurang sensitif kerukunan, dapat berdampak pada terganggunya kerukunan umat beragama.

3. Kemajuan teknologi, selain banyak sisi positifnya juga membawa dampak negatif yang cukup rawan dalam perspektif kerukunan umat beragama. Saat ini, dengan mudahnya seseorang mem-posting suatu status/statemen atau mengunggah suatu 
video yang mengandung substansi penyebaran agama pada pemeluk agama lain via Youtube. Dalam tingkat tertentu, "kreativitas" ini terkadang menyerempet kelompok lain, yang ujungnya dapat mengeskalasi pertentangan.

\section{Analisa}

Karakter masyarakat Kota Makassar yang relijius dan berbudaya menjadi ruang yang kondusif bagi terlaksananya proses penyiaran agama-agama dalam kondisi baik, mendukung pemeliharaan kerukunan umat beragama. Namun demikian, heterogenitas latar belakang agama, suku, dan budaya serta perkembangan kota perdagangan dan bisnis, menjadi tantangan tersendiri dalam konteks penyiaran agama di kota ini.

Apakah SKB No. 1 Tahun 1979, berdasarkan perspektif/respon masyarakat, telah terimplementasi? Atau, bagaimana masyarakat melihat implementasinya itu? Berikut tabel evaluasi untuk membantu merangkum data-data dan informasi di atas:

Tabel 3. Evaluasi Implementasi Substansi SKB No.

\begin{tabular}{|c|c|c|}
\hline $\begin{array}{c}\text { Substansi SKB } 1 \\
\text { Tahum 1979 }\end{array}$ & $\begin{array}{c}\text { Respon atau } \\
\text { Fakta lappangan }\end{array}$ & Ok? \\
\hline $\begin{array}{l}\text { Tidak menyi ark an agama } \\
\text { pada orangyang sudah } \\
\text { memeluk agama; dan } \\
\text { dengan disertai bujuk an } \\
\text { materi tertentu. }\end{array}$ & $\begin{array}{l}\text { - Di Makasar tidak adalagi praktik penyiaran agama } \\
\text { melalui bujukan, paksaan, atau pemberian materi } \\
\text { tertentu. Respon semua repponden demikian, meski } \\
\text { observasi lapangan dan perkembangan terbaru ad a } \\
\text { indikasi praktik derikian. } \\
\text { - Penyebaran agamamel alui bahan cetakan juga tidak } \\
\text { menonjol ada } \\
\text { - Penyiaran agama dengan cara doorto-door pada } \\
\text { umumnya tidak adal agi, kecuali apa yang dil akukan } \\
\text { olehkelompok Saksi Yehuw a, di lingkungan Kristen. }\end{array}$ & $\begin{array}{l}\cdot \mathrm{Ok} \\
\cdot \mathrm{OK} \\
\text { - Ok }\end{array}$ \\
\hline $\begin{array}{l}\text { Memberikan laporan pada } \\
\text { Pemerintah atas bantuan } \\
\text { danadan/atau tenaga } \\
\text { keagamaan dari luar negeri; } \\
\text { juga diklat bagi WNI } \\
\text { pengganti rohaniawan asing }\end{array}$ & $\begin{array}{l}\text { - Tidak ada satupunl aporan tentang penerimaan dana } \\
\text { bantuan dari luar negeri kelembaga keagamaan lok al. } \\
\text { - Demikian juga, tidak ada catatan tau laporan tentang } \\
\text { aktivitas tenaga asing di lembagakeagamaan di } \\
\text { Makasar. } \\
\text { - Diklat khusus penyiap an tenaga asing tidak ada, } \\
\text { melaink an digunak an mekanisme lok d dari sekol ah } \\
\text { dan kampus. }\end{array}$ & $\begin{array}{l}\cdot \mathrm{x} \\
\cdot \mathrm{x} \\
\cdot \mathrm{OK}\end{array}$ \\
\hline $\begin{array}{l}\text { Peran Pemerintah Daerah } \\
\text { (guberruur/bup/walkot- } \\
\text { kak anwil/kankemenag) dlm } \\
\text { implementasi SKB 1/1979 }\end{array}$ & $\begin{array}{l}\text { - Pemkot Makasar memaks smalkan peran Muspida dan } \\
\text { pakem Sed angkan Kemenag Kota Makasar } \\
\text { mengoptimakan peran peryuluh agama dal an } \\
\text { melihat implementasi SKB ini. }\end{array}$ & $\cdot \mathrm{Ok}$ \\
\hline
\end{tabular}

Dari gambaran pada tabel di atas, tampak bahwa secara empirik SKB No. 1/1979 telah berjalan atau terimplementasi di Kota Makassar, kecuali pada bagian pelaporan dana bantuan luar negeri dan bantuan tenaga asing untuk lembaga keagamaan. Namun demikian, ada potensi konfliktual yang cukup besar terkait penyiaran agama dalam konstruk masyarakat Makassar yang semakin heterogen dan terbuka, dalam dinamika politik lokal.

Kesbangpolinmas merasa perlu penguatan peraturan soal penyiaran agama, di SKB tidak terlalu banyak disinggung masalah sanksi, SKB diusulkan menjadi UU. Terkait substansi, agar ada aturan bahwa suatu kelompok tidak menyalahkan kelompok lain. Kalangan umat beragama pun membutuhkannya. MUI berpendapat karena pemahaman agamanya kurang, sehingga terlalu mudah menyalahkan pihak lain. Perlu regulasi yang menengahinya, termasuk pengaturan terkait penggunaan pengeras suara. Perwakilan tokoh agama juga memandang Pemerintah perlu mengatur ihwal lalu lintas penyiaran agama ini demi terciptanya ketertiban dan kerukunan umat beragama.

Dari paparan di atas, secara akademis penting dicermati wacana mengenai konsep implementasi hukum. Menurut Asshiddiqie, hukum dalam arti luas meliputi keseluruhan aturan normatif yang mengatur dan menjadi pedoman perilaku dalam kehidupan bermasyarakat dan bernegara dengan didukung oleh sistem sanksi tertentu terhadap setiap penyimpangan terhadapnya. ${ }^{25}$ Maka dalam implementasi hukum, selain memerlukan sosialisasi dan edukasi masyarakat terkait hukum atau regulasi dimaksud, juga perlu didukung sanksi atas penyimpangannya. Penelitian ini membuktikan, kurangnya sosialisasi dan lemahnya kekuatan hukum SKB menyebabkan potensi ketidakrukunan karena penyiaran agama masih ada.

Sementara itu, secara empirik, diskursus penyiaran agama kerap dilekatkan dengan kasus kerukunan atau gangguan ketertiban sosial. Di sisi lain, secara teoritik, kehadiran suatu regulasi dimaksudkan untuk menciptakan ketertiban dalam masyarakat dan menjadi jembatan dari berbagai kepentingan. Maka temuan penelitian ini dapat berkontribusi mendorong implementasi atau bahkan penguatan regulasi penyiaran agama untuk tetap terciptanya kerukunan antarumat beragama.

\section{E. Penutup}

Dari paparan di atas, dapat disimpulkan beberapa hal sebagai berikut:

1. Praktik penyiaran agama di Kota Makassar telah berjalan baik, hanya saja terkait pelaporan dana luar negeri untuk lembaga

${ }^{25}$ Jimly Asshiddiqie, Hukum Tata Negara dan Pilar-Pilar Demokrasi (Jakarta: Konstitusi Press, 2006), 3. 
keagamaan dan bantuan tenaga asing belum ada pelaporannya. Penyiaran dengan media tertulis tidak ada masalah, namun penyiaran door-to-door diketahui masih ada yang melakukannya.

2. Faktor pendukung terimplementasikannya SKB 1/1979 adalah adanya keinginan masyarakat untuk damai, peran regulatifedukatif Pemerintah, serta modal sosial hubungan lintas agama yang telah terjalin cukup baik. Sedangkan hambatannya, selain kekurangtahuan dan kekurangpahaman atas regulasi (SKB), juga tantangan pemahaman HAM yang salah, serta side effect kemajuan teknologi komunikasi yang kontraproduktif untuk penyiaran agama dan kerukunan umat beragama.

Berdasar simpulan di atas, direkomendasikan beberapa hal sebagai berikut:

1. Perlu pemutakhiran SKB No. 1 Tahun 1979 mengikuti tuntutan penyesuaiannya dengan
UU No. 32 Tahun 2004, sekaligus menyempurnakan substansinya mengikuti perkembangan zaman. Kajian akademis untuk menyinkronkannya dengan UU tentang ITE, UU tentang Penyiaran, dan sebagainya juga penting dilakukan. Regulasi tentang pengaturan akuntabilitas lembaga keagamaan agar diperkuat dengan di-entrykan ke dalam RUU Keormasan. Di samping itu, sosialisasi aturan ini juga perlu digalakkan.

2. Perlu dilakukan kajian lebih jauh tentang peran media cetak dan elektronik (termasuk media sosial) terkait penyiaran agama, serta kaitannya dengan pemeliharaan kerukunan umat beragama.[] 
Asry, Yusuf, (Ed.). Gerakan Dakwah Islam dalam Perspektif Kerukunan Umat Beragama. Jakarta: Puslitbang Kehidupan Keagamaan, Badan Litbang dan Diklat Kementerian Agama, 2012.

Hakim, Bashori A. dan Titik Suwaryati, (Ed.). Pandangan Masyarakat terhadap Penyiaran/ Dakwah Agama. Jakarta: Puslitbang Kehidupan Keagamaan, Badan Litbang dan Diklat Kementerian Agama, 2007.

Hasanah, Uswatun. Solidaritas Sosial (Kasus pada Komunitas Wahdah Islamiyah di Kota Makasar). Makasar: Program Pascasarjana Universitas Negeri Makasar, 2010.

Karim, Muchith, A. "Penyiaran Agama dalam Perspektif Islam dan Kristen di Panakkukang, Kota Makasar", dalam Harmoni, Volume X Nomor 2 April-Juni 2012.

Makasar Dalam Angka 2012. Makasar: BPS Kota Makasar, 2012.

Moleong, Lexy J. Metodologi Penelitian Kualitatif. Bandung: PT Remaja Rosdakarya, 2002.

Laman www.indonesia.ucan-news.com/2013/08/20/ pemkot-Makasar-larang-pengobatan-gratisdari-seorang---pen-deta/diunduh pada 30 September 2013.
Laporan Asia Briefing No. 114, Indonesia: "Christianisation" and Intolerance, yang diterbitkan Interna-tional Crisis Group, www.icg.org, yang dirilis pada 24 November 2010.

Said, Nurman. Masyarakat Muslim Makasar: Studi tentang Pola-pola Integrasi Sosial antara Muslim Pagama dengan Muslim Sossorang, Disertasi. Yogyakarta: UIN Sunan Kalijaga, 2007.

Sairin, Weinata. Himpunan Peraturan di Bidang Keagamaan. Jakarta: BPK Gunung Mulia, 1994.

Tim Penyusun. Kompilasi Peraturan Perundangundangan dan Kebijakan Kehidupan Beragama. Jakarta: Puslit-bang Kehidupan Keagamaan, 2011. 